\title{
Perceived effects of Pornography Consumption Among Men: A Comparative Study of Homosexual and Heterosexual Men
}

\author{
Mohit Sholapurkar ${ }^{1}$, Ganpat K. Vankar², Avinash De Sousa ${ }^{3}$ \\ 1Resident Doctor, \\ ${ }^{2}$ Professor and Head, \\ Department of Psychiatry, B.J. Medical College, Ahmedabad. \\ ${ }^{3}$ Research Associate, Department of Psychiatry, Lokmanya Tilak Municipal Medical College, Mumbai \\ E-mail - avinashdes888@gmail.com
}

\begin{abstract}
Background: With the advancement in Media technologies, explicit sexual materials are widely available and distributed easily. This exposes people to pornography as never before. Consumption of it may potentially be stimulating as well as may lead to development of ill effects such as aggression, paraphilias. We aimed to study the effects of pornography consumption over two different groups i.e. heterosexual men and homosexual men.

Methodology: We conducted a comparative study among homosexual males and heterosexual males who consumed porn. Pornography Consumption Effect Scale (PCES), 47 item likert scale was used for assessing various positive as well as negative domains associated with Porn consumption. Besides we explored the effects by face to face interviews of individuals in both the groups to further deepen our understanding.

Results: Overall scores of positive domains such as sex life, knowledge, and attitude were on much higher side compared to scores suggestive of negative domains. Most of the respondents considered porn useful rather than harmful. The results were analyzed considering both i.e. qualitative as well as quantitative perspectives and responses obtained from sample population.

Conclusions: Pornography consumption can be double edged sword. It should be buffered with base of scientific knowledge and sex education to avoid negative consequences.
\end{abstract}

Keywords: Pornography, Homosexual, Heterosexual, consumption.

(Paper received $-29^{\text {th }}$ April 2016, Peer review completed $-9^{\text {th }}$ June 2016, Accepted $-19^{\text {th }}$ June 2016)

\section{INTRODUCTION}

Viewing pornography has always been an issue of havoc. The availability of pornography in mass media (newspapers, magazines, films, television, and internet) has increased at the same rate as the technological development has made production and distribution of pornography simpler [1]. The term pornography is often negatively loaded, and associated with the socially unacceptable, the deviant, the censured, or the shameful [2-3]. Pornography functions as means of entertainment, sexual arousal and stimulation, and as an information source about sexuality, particularly for young people [4-5].

Pornography is defined as 'Any kind of material aiming at creating or enhancing sexual feelings or thoughts in the recipient and at the same time containing explicit exposure and/or descriptions of the genitals and clear and explicit sexual acts such as vaginal intercourse, anal intercourse, oral sex, masturbation, bondage, sadomasochism, rape, animal sex etc [6].

There is paucity of studies on the impact of pornography on the society, most are flawed. Various domains of the pornography consumption are studied such as addiction, aggression, extramarital sexual behavior, 
paraphiliac behavior, gender difference in the patterns of the consumption of pornography etc [7]. Men appear to be more attracted to and consume more pornography than women, be more attracted to hardcore pornography devoid of relationship context and emotional attachments, get more psychologically aroused viewing pornography [8]. Men tend to get easily aroused by visual sexual stimuli compared to women. Gender differences exist on almost all variables related to exposure to and use of pornography [9]. Compared to women, men use pornography more often during solitary sexual activity (e.g. masturbation). Males are exposed to pornography at a comparatively younger age, and spend more time per week watching pornography. Men more often enjoy pornography in the company of friends or most of the time on their own, vice versa females tend to enjoy porn in the company of their sexual partners [10]. Gay/bisexual men and lesbian/bisexual women reported higher use of pornography than straight men and women [11].

The three most important motives for exploring sex on the internet are to become sexually aroused, curiosity, and to improve the sex life with a partner in the real life [12]. Sexual activity on the internet comprise activities related to finding partners, watching erotica, participating in erotic chatting, buying sex toys, seeking help for sexual problems, or having cybersex. More gay/bi men and lesbian/bi women than straight people reported exposure to pornography in all media. They additionally reported more frequent use. The difference was particularly noticeable between lesbian/bi women and straight women and in relation to use of the internet to watch pornography and chat. This could imply that lesbian/bi women are more partner-independent in their use of pornographic materials than straight women porn [13-14].

Table 1 - Few studies done in the context of Pornography Use

\begin{tabular}{|c|c|c|}
\hline Researchers & Methods & Findings \\
\hline Rolness (2003) [15] & $\begin{array}{l}\text { Described in a debate about } \\
\text { overall social perception of } \\
\text { watching Porn }\end{array}$ & $\begin{array}{l}\text { Public debate is dominated } \\
\text { by a view of pornography as something } \\
\text { immoral and } \\
\text { harmful to people. }\end{array}$ \\
\hline Traeen et al (2002) [16] & $\begin{array}{l}\text { Did survey of Prevalence of } \\
\text { Pornography consumption }\end{array}$ & $\begin{array}{l}90 \% \text { of Norwegians older than } 15 \text { years of } \\
\text { age reported exposure to pornography at } \\
\text { some point in their life }\end{array}$ \\
\hline Brown, (2002) [17] & $\begin{array}{l}\text { Studied mass media } \\
\text { influences on Sexuality }\end{array}$ & $\begin{array}{l}\text { Internet has increased the availability of } \\
\text { sexually explicit } \\
\text { material dramatically }\end{array}$ \\
\hline $\begin{array}{l}\text { Goodson, McCormick, } \\
\text { and Evans (2001) [18] }\end{array}$ & $\begin{array}{l}\text { An exploratory study of } \\
\text { American college student's } \\
\text { behavior and attitude }\end{array}$ & $\begin{array}{l}\text { Found that } 44 \% \text { of } \\
\text { American students had watched } \\
\text { pornography on the internet, and there } \\
\text { were significant gender differences in use. }\end{array}$ \\
\hline $\begin{array}{l}\text { McKenna and Bargh } \\
\text { (2000) [19] }\end{array}$ & $\begin{array}{l}\text { The implications of the } \\
\text { internet for personality and } \\
\text { social psychology. }\end{array}$ & $\begin{array}{l}\text { Sexual meetings on the internet may } \\
\text { function as an intermediate station between } \\
\text { fantasy and realization of fantasies. }\end{array}$ \\
\hline $\begin{array}{l}\text { Staley and Prause } \\
(2013)[20]\end{array}$ & $\begin{array}{l}\text { Erotica viewing effects on } \\
\text { intimate relationships and } \\
\text { self/partner evaluations. }\end{array}$ & $\begin{array}{l}\text { Participants viewing both the erotic and } \\
\text { exciting films reported equivalent increases } \\
\text { in excitement; however, the erotic film was } \\
\text { rated as slightly more generally arousing } \\
\text { and increased participant's desire to be } \\
\text { close to their partner. }\end{array}$ \\
\hline
\end{tabular}




\begin{tabular}{|lll|}
\hline Sahay et al. (2013) [21] & $\begin{array}{l}\text { Correlates of Sex Initiation } \\
\text { among School Going } \\
\text { Adolescents in Pune, India. }\end{array}$ & $\begin{array}{l}\text { Adolescents studying in vernacular } \\
\text { schools, accessing pornography and having } \\
\text { unfriendly relationship with parents had } \\
\text { higher likelihood of sex initiation. }\end{array}$ \\
\hline Singh et al.(2010) [22] & $\begin{array}{l}\text { Determinants of alcohol } \\
\text { use, risky sexual behavior } \\
\text { and sexual health problems } \\
\text { among men in low income } \\
\text { communities of } \\
\text { Mumbai, India. }\end{array}$ & $\begin{array}{l}\text { One of the determinants studied was } \\
\text { Pornography consumption. }\end{array}$ \\
& & \\
\hline
\end{tabular}

The aim of the current research was to study the perceived effects of viewing Pornography in males and to compare the perceived effects of Pornography consumption between Heterosexual Males and Males having Sex with Males (MSM).

\section{METHODOLOGY}

Men, heterosexual or homosexual, who were currently sexually active and have watched porn at least once during last one month, were interviewed.

\section{Instrument}

Pornography Consumption Effect Scale (PCES) (Hald and Malmuth) [23], a Likert Scale (Responses from 1 to 6) was used to measure effects of pornography consumption. There are 47 questions in the scale. These 47 questions are subdivided into various domains as follows.

Sex Life (SL) - (5 items for PED*; 8 items for NED*), To explore effects of consumption on one's sex life and sexual behaviors (e.g., effects on the frequency of sexual activity, sexual experimentation, and sexual performance). [PED - positive effect dimension, NED - negative effect dimension].

2. Life in General (LG) - (4 items for PED; 4 items for NED). To investigate effects of pornography consumption on life in general (e.g., on the quality of life, satisfaction with life, and problems in life).

3. Perception of and Attitudes Toward the Opposite Gender (PATOG) - (4 items for PED; 3 items for NED). To tap into effects of consumption on the perception of and attitudes towards the opposite gender (e.g., stereotypical perceptions of gender, friendliness toward and respect for the opposite gender).

4. Attitudes Toward Sex (ATS) - ( 5 items for PED; 5 items for NED). To investigate effects of consumption on Attitudes Toward Sex (e.g., opinions, views, and outlook on sex).

5. Sexual Knowledge (SK) - (9 items, PED only). To examine effects of consumption on knowledge of sex and sexual desire (e.g., masturbation, sexual foreplay, oral, vaginal, and anal sex, sexual fantasies, and sexual desires).

Males with Heterosexual orientation were chosen from the Married Security guards who guarded at the entrance of the different wards in Civil Hospital, Ahmedabad. Males with Homosexual orientation were chosen from an organization working for Males having Sex with Males (Gram Vikas Trust ) in Ahmedabad. All the males who were indulging in homosexual activity were passive partners. Most of these males used to gather together after $10 \mathrm{pm}$ (ending with their dinner and daily job) in one Lawn at Cross Roads near Ahmedabad Railway Station. There they would chat with each other, share tea, snacks, cigarettes, country liquor with each other. Interviewer visited this hangout every night for more than three weeks for collection of the data from MSM. Each of the participants was interviewed at length in one to one setting. Name and identity was kept confidential. They were asked overall open ended questions as What is your opinion about watching porn movies?

What are benefits and disadvantages of watching porn?

Will you advise any friend of yours to watch porn? 
All the answers were recorded verbatim. After the rapport was established, they were asked to rate each item in PCES Scale from 1 to 6 . They were explained each item in the questionnaire in the language of their preference i.e. Hindi or Gujarati. It took on an average 30 Minutes to interview each respondent and rate the PCES Scale.

\section{STATISTICAL ANALYSIS}

The data was entered into an excel sheet and SPSS version 19.0 was used in the assessment. Statistics using the unpaired $t$ test and Fischer's exact test was used where appropriate.

\section{RESULTS}

A total of 74 men were interviewed, 44 with heterosexual orientation and 30 with homosexual orientation.

Table 2 - Characteristics of Respondents

\begin{tabular}{|c|c|c|c|c|}
\hline & & $\begin{array}{l}\text { MSM } \\
\mathrm{N}=30 \\
\mathrm{~N}(\%)\end{array}$ & $\begin{array}{l}\text { Heterosexual } \\
\mathrm{N}=44 \\
\mathrm{~N}(\%)\end{array}$ & \\
\hline Age & $\begin{array}{l}20-25 \\
26-30 \\
31-35 \\
36-40 \\
41-45 \\
\text { Range } \\
\text { Mean (SD) }\end{array}$ & $\begin{array}{l}6(20.0) \\
5(16.7) \\
6(20.0) \\
2(6.7) \\
11(36.7) \\
27-54 \\
36.53(9.99)\end{array}$ & $\begin{array}{l}5(11.4) \\
23(52.3) \\
13(29.5) \\
0 \\
3(6.8) \\
32-42 \\
36.09(10.12)\end{array}$ & $\begin{array}{c}\mathrm{t}=0.1846 \\
\mathrm{df}=72 \\
\mathrm{p}=0.8541 \mathrm{NS}\end{array}$ \\
\hline $\begin{array}{l}\text { Overall Perception } \\
\text { of pornography as } \\
\text { enhancer of sexual } \\
\text { functioning }\end{array}$ & $\begin{array}{l}\text { Yes } \\
\text { No }\end{array}$ & $\begin{array}{l}26(86.7) \\
04(13.3)\end{array}$ & $\begin{array}{l}36(81.8) \\
8(18.2)\end{array}$ & $\begin{array}{l}\text { Fisher exact test } \\
\text { two-tailed } \\
\mathrm{p}=0.7511 \mathrm{NS}\end{array}$ \\
\hline
\end{tabular}

\section{Quantitative data analysis}

Age

Minimum age of the respondent was 21 years and maximum was 54 years. Considering age range $27-54$ for MSM, mean obtained was 36.53 years and age range for heterosexual males was 32- 42 ,mean obtained was 36.09 years. Mean age for MSM was slightly higher as compared to heterosexual males. $(\mathrm{t}=0.18$, df $=72, \mathrm{p}=0.8541$ )

\section{Overall perception of Pornography as enhancer of sexual functioning}

$86.7 \%$ MSM and $81.8 \%$ heterosexual males said Pornography consumption enhances sexual functioning. This perception is on higher side in MSM compared with Heterosexual Males .( Fisher exact test, two tailed, $\mathrm{p}=0.7511$ )

\section{Sex Knowledge and Sex Life}

Mean scores for gain in sexual knowledge were 45.60 and 41.89 respectively for MSM and Heterosexual males. $(\mathrm{t}=1.71, \mathrm{df}=72, \mathrm{p}=0.02)$ Scores for Overall impact of viewing porn on life were 30.27 and 27.73 respectively for MSM and heterosexual males. $(\mathrm{t}=2.24, \mathrm{df}=72, \mathrm{p}=0.0281)$ Scores in both these domains are almost similar to each other in the two categories.

\section{Life in General}

Impact on overall quality of life after watching Porn was tested and mean scores are 22.80 and 19.09 ,for MSM and Heterosexual males respectively. Scores are similar for the two groups. $(t=2.4933, \mathrm{df}=72$, $\mathrm{p}=0.0150)$ 
Table 3 - The Pornography Consumption Effect Scale (PCES)

\begin{tabular}{|c|c|c|c|}
\hline Dimension & $\begin{array}{l}\text { MSM } \\
\mathrm{N}=30 \\
\text { Range } \\
\text { Mean(SD) }\end{array}$ & $\begin{array}{l}\text { Heterosexual } \\
\mathrm{N}=44 \\
\text { Range } \\
\text { Mean(SD) }\end{array}$ & \\
\hline $\begin{array}{l}\text { SK : Sexual } \\
\text { Knowledge }\end{array}$ & $\begin{array}{l}10-58 \\
45.60(10.21)\end{array}$ & $\begin{array}{l}16-86 \\
41.89(12.9)\end{array}$ & $\begin{array}{l}\mathrm{t}=1.32 \\
\mathrm{df}=72 \\
\mathrm{p}=0.1917 \mathrm{NS}\end{array}$ \\
\hline SL : Sex Life & $\begin{array}{l}21-38 \\
30.27(3.84)\end{array}$ & $\begin{array}{l}14-39 \\
27.73(5.33)\end{array}$ & $\begin{array}{l}\mathrm{t}=2.24 \\
\mathrm{df}=72 \\
\mathrm{p}=0.0281 \mathrm{NS}\end{array}$ \\
\hline LG: Life in General & $\begin{array}{l}12-30 \\
22.80(4.86)\end{array}$ & $\begin{array}{l}7-37 \\
19.09(7.09)\end{array}$ & $\begin{array}{l}\mathrm{t}=2.49 \\
\mathrm{df}=72 \\
\mathrm{p}=0.0150^{*}\end{array}$ \\
\hline $\begin{array}{l}\text { ATS : Attitude } \\
\text { towards Sex }\end{array}$ & $\begin{array}{l}16-41 \\
32.67(5.93)\end{array}$ & $\begin{array}{l}10-37 \\
26.68(6.63)\end{array}$ & $\begin{array}{l}\mathrm{t}=3.98 \\
\mathrm{df}=72 \\
\mathrm{p}=0.0002 *\end{array}$ \\
\hline $\begin{array}{l}\text { PATOG : Perception } \\
\text { of and attitude } \\
\text { towards the opposite } \\
\text { Gender }\end{array}$ & $\begin{array}{l}28-42 \\
35.60(2.65)\end{array}$ & $\begin{array}{l}16-48 \\
33.18(5.95)\end{array}$ & $\begin{array}{l}\mathrm{t}=2.09 \\
\mathrm{df}=72 \\
\mathrm{p}=0.0404^{*}\end{array}$ \\
\hline $\begin{array}{l}\text { P: Positive effect } \\
\text { dimension }\end{array}$ & $\begin{array}{l}58-157 \\
131.10(20.44)\end{array}$ & $\begin{array}{l}50-162 \\
115.93(28.60)\end{array}$ & $\begin{array}{l}\mathrm{t}=2.50 \\
\mathrm{df}=72 \\
\mathrm{p}=0.0147^{*}\end{array}$ \\
\hline $\begin{array}{l}\mathrm{N}: \text { Negative effect } \\
\text { dimension }\end{array}$ & $\begin{array}{l}22-65 \\
35.83(8.86)\end{array}$ & $\begin{array}{l}21-68 \\
33.95(8.40)\end{array}$ & $\begin{array}{l}\mathrm{t}=0.92 \\
\mathrm{df}=72 \\
\mathrm{p}=0.3583 \mathrm{NS}\end{array}$ \\
\hline $\begin{array}{l}\text { SK } \\
\text { ATS } \\
\text { PATOG } \\
\text { LG } \\
\text { SL }\end{array}$ & $\begin{array}{l}1,8,9,14,16,23, \\
2,3,18,19,26,3 \\
4,7,15,20,35,36 \\
5,10,11,12,17,2 \\
6,13,21,22,27,2\end{array}$ & & \\
\hline $\begin{array}{l}\text { Overall Positive Effect } \\
=\text { average of the } \\
\text { following items }\end{array}$ & $\begin{array}{l}1,3,8,9,11,12 \\
31,33,36,38,\end{array}$ & $1,23,24,27,28$ & \\
\hline $\begin{array}{l}\text { Overall Negative } \\
\text { Effect = average of the } \\
\text { following items }\end{array}$ & $\begin{array}{l}2,4,5,6,7,10 \\
40,44,46,47\end{array}$ & $32,34,35,37$ & \\
\hline
\end{tabular}

*significant, NS - not significant, Unpaired t test used in the assessment

\section{Attitude towards Sex}

After watching porn, how was the attitude of the respondents was evaluated and the mean scores were 32.67 and 26.68 for MSM and Heterosexual males respectively. Scores are similar for two $\operatorname{groups}(\mathrm{t}=3.98, \mathrm{df}=72, \mathrm{p}=0.0002)$. 


\section{Perception of and attitude of opposite Gender}

Is there any change in the attitude of the male towards the female was tested through this question and the mean scores were 35.60 and 33.18 respectively for MSM and heterosexual males. Scores are similar in both groups $(\mathrm{t}=2.0876, \mathrm{df}=72 . \mathrm{p}=0.0404)$.

\section{Positive effect dimension}

Responses in favor of Positive effect of watching porn were evaluated and the mean scores were 131.10 and 115.93 respectively for MSM and heterosexual males. Here the difference between Positive effect dimension of watching porn is significant among these two groups, MSM reporting higher mean score value. $(\mathrm{t}=2.5, \mathrm{df}=72, \mathrm{p}=0.0147)$

\section{Negative effect dimension}

Responses in oppose of watching porn were evaluated and the mean scores were 35.83 and 33.95 for MSM and heterosexual males respectively. Here the scores are on lesser side as compared to the responses obtained for Positive effect dimension. Also there was no difference in the negative effect dimension scores obtained from the two groups. $(\mathrm{t}=0.9245, \mathrm{df}=72, \mathrm{p}=0.3583)$

\section{DISCUSSION}

\section{MSM Subculture}

MSM as a group comprise of more than 4500 males scattered all over the city. They have typical code words and terms used among them and also for locating their Customers. Some of them walk and speak in very typical Feminine attire and they always prefer to remain clean shaved. They also trim their Eyebrows to look Sharp. All these things are done to attract the male customers or even to please their male partners who are committed to them. In this MSM community each person has two names. One is the original name and the other is Feminine name. While interviewing, many of them narrated that they hardly get erotic feelings on seeing person of the opposite sex. Some of the MSM are fathering the children but report that they never get aroused to make love with their female partners and on the other hand they starve for even few minutes of physical proximity with their male partners or customers. Some of the MSM narrated that they leave their home late night and wander on the roads in search of partner. Few areas in Ahmedabad are known as Pick Up Points where these affairs are carried out. Public urinals are one of them.

Age

Almost all of respondents replied their age when they viewed pornography for the first time was around 16 to 22 years. And still the respondents continued to view pornography. This indicates the persistence in the process of the consumption of the Pornography.

\section{Pornography material}

Source for watching pornography was mobile phones for all the respondents. This indicates easy availability of the pornography material and easy circulation among friends with the help of Bluetooth and Android software. Some of them preferred to see porn movies in theatres, LCD screens, personal computers as well.

\section{Sexual Knowledge and Sex Life}

Most of the men gave the history that they watch porn, often to get an arousal and to masturbate. Frequency of the masturbation was much more prior their marriage and it reduced after marriage as they indulged in heterosexual activity. They identify with the Porn Actor on video, fantasize and get stimulated. Carrying the mobile phones in any room, lavatories or any place where they will get privacy was easy. If the porn videos were not available, they recall the earlier viewed scenes and get stimulated. They also learned and practiced various different methods of masturbation after watching porn. Eg. Masturbating after putting a condom, after applying a soap leather over genitalia, masturbation in prone position, mutual masturbation, masturbation in the mouth or over body of the partner etc.

Some also reported that viewing porn was beneficial to get stimulated and masturbate if the partner was not available. Many of the respondents added that they got accurate knowledge about the anatomy of the female genitals. This helped them during their beginnings of the sexual career. Rather some remarked, 
Watching porn benefitted them a lot for understanding various coital positions. As responded to the question "Did it make you to experiment more in your sexual life ?",they reported that watching porn also has validated their fantasies. For example, sex in the bathroom, sex in standing position, penetration from rear side, oral sex etc.

'It helped us to spend more and more time in the bed which was satisfying for our partners as well' said few. They followed activities shown in porn and started exploring their fantasies. Porn gave much needed confidence to many at the occasion of their very first sexual intercourse.

\section{Attitude toward Sex}

Overall watching porn was a stimulating experience for most of the respondents and it influenced positively their outlook on sex. Few respondents said that they preferred to see the porn with their partners, so that partners get liberated sexually and get ready to experiment. Most of the respondents opined that they benefited of watching porn. By and large it reflects positive attitude of them considering personal sex life and watching Porn.

\section{Life in General}

Considering watching porn and its effects on life in general, it had valuable contribution to viewer's lives and it improved quality of life and typically made life less problematic.

\section{Perception of and attitude towards the gender of opposite sex}

In our study .the scores obtained were almost similar to each other. Some of the studies have shown that consumption of pornography may lead to aggression, rape, paraphiliac interests. The male may assume female partner as an object of lust. In this study the scores were on higher side indicating good perception and friendly attitude towards the person of the opposite sex. On the other hand MSM described erotic feelings towards young males and though feelings were erotic, their attitude was not negative.

\section{Pornography Consumption and Unmet Sex Needs of MSM}

Some of the MSM interviewed worked as Male Commercial Sex Workers. At the location where they meet daily, some of them wait for their male customers who take one of them for sex at some lodge, public toilets etc. Few of MSM have rented rooms specially for sexual liaisons with their male customers. Many of them have their regular customers who just ring the horn near the lawn at a particular timing and the male CSW goes with him. Sometimes group of three or four men hire an auto rickshaw and pick up one of the Male CSW for Group Sex. These auto rickshaw drivers are also among their familiar circle. Some of the MSM visit the hang out with their committed male partners. As the time passes, one by one they gather together and chat with each other.

Most of MSM prefer to watch porn where homosexual activities are depicted. Most of them got validated that they bear erotic and romantic feelings towards the men after watching such gay porn. Being sexual minority, they cannot discuss homosexual activities as freely as heterosexual activities. To explore their fantasy world, MSM often preferred to watch gay porn. Porn informed and widened range of sexual activities of MSM, like anal sex, oral sex, mutual masturbation, penetrative intercourse using thighs, axillae, breasts, one of the partner getting cross dressed. Of these, oral sex and anal sex were the most common sexual activities they engage in. MSM sometimes preferred to watch heterosexual activities to get an idea about how a female partner pleases and stimulates the man. MSM often got insight how to make their partners more interested and excited. Some of the Male CSWs had big screen television at their place where the CSW and his male customer watch the porn together before indulging in sexual activity. Many used pornography for getting erection soon after an ejaculation. MSM often used porn to make their active partners ready for next penetrating attempt.

Making an overall comparison of frequency of pornography consumption between heterosexual males and MSM, the later tend to have more frequent, as often as daily consumption. This difference can be attributed to unmet sexual needs of MSM compared to sexually satisfied married heterosexual men. That is also the one of the reason behind excess indulgence in substance consumption among MSM.

The strengths of the study are that it is the first of such kind of study in India assessing Pornography Consumption Effect. It is the first study where heterosexual and homosexual men were compared. In the study both qualitative and quantitative data was collected. The study was limited by small sample size, respondents who were poor or middle class and less educated men. The findings cannot be generalized due to these limitations. 


\section{CONCLUSIONS}

This study gives us clear insight about widespread consumption of Pornography. We need to assess Perceived Effects of pornography Consumption with an open eye. MSM often indulge in watching porn in excess and may get involved in unsafe sex practices and substance use disorders. Recognizing this group and motivating them for coming out process will actually help them more. Psychiatrists dealing with male sexual dysfunctions in day to day clinical practice may make use of pornography to demonstrate useful activities like foreplay. Sex education at root level and free communication will help more to deal with the doubts, questions.

\section{REFERENCES}

1. Hald GM, Malamuth NM. Self-perceived effects of pornography consumption. Arch Sexual Behav 2008;37(4):614-25.

2. Hald GM. Gender differences in pornography consumption among young heterosexual Danish adults. Arch Sexual Behav 2006;35(5):577-85.

3. Häggström-Nordin E, Hanson U, Tydén T. Associations between pornography consumption and sexual practices among adolescents in Sweden. Int J STD AIDS 2005;16(2):102-7.

4. Wright PJ. US males and pornography, 1973-2010: Consumption, predictors, correlates. J Sex Research 2013;50(1):60-71.

5. Endrass J, Urbaniok F, Hammermeister LC, Benz C, Elbert T, Laubacher A, Rossegger A. The consumption of Internet child pornography and violent and sex offending. BMC Psychiatry 2009;9(1):43.

6. Kühn S, Gallinat J. Brain structure and functional connectivity associated with pornography consumption: the brain on porn. JAMA Psychiatry 2014;71(7):827-34.

7. Lambert NM, Negash S, Stillman TF, Olmstead SB, Fincham FD. A love that doesn't last: Pornography consumption and weakened commitment to one's romantic partner. J Soc Clin Psychol 2012;31(4):410-38.

8. Sabina C, Wolak J, Finkelhor D. The nature and dynamics of Internet pornography exposure for youth. Cyberpsychol Behav 2008;11(6):691-3.

9. Zillmann D, Bryant J. Pornography's impact on sexual satisfaction. J Appl Soc Psychol 1988;18(5):438-53.

10. Hald GM, Smolenski D, Rosser BR. Perceived effects of sexually explicit media among men who have sex with men and psychometric properties of the Pornography Consumption Effects Scale (PCES). J Sexual Med 2013;10(3):757-67.

11. Wright PJ, Randall AK. Pornography consumption, education, and support for same-sex marriage among adult US males. Commun Res 2014;41(5):665-89.

12. Flood M. The harms of pornography exposure among children and young people. Child Abuse Rev 2009;18(6):384-400.

13. Weinberg MS, Williams CJ, Kleiner S, Irizarry Y. Pornography, normalization, and empowerment. Arch Sexual Behav 2010;39(6):1389-401.

14. Weitzer R, editor. Sex for sale: Prostitution, pornography, and the sex industry. Routledge; 2009.

15. Rolness K. Sex, løgn og videofilm. Et usladdet oppgjør med mytene om porno [Sex, lies and videofilm. A not blanked out settlement with the myths about pornography]. Oslo, Norway: Aschehoug forlag as. 2003.

16. Træen B, Nilsen TS, Stigum H. Use of pornography in traditional media and on the Internet in Norway. J Sex Research 2006;43(3):245-54.

17. Brown JD. Mass media influences on sexuality. J Sex Research 2002;39(1):42-5.

18. Goodson P, McCormick D, Evans A. Searching for sexually explicit materials on the Internet: An exploratory study of college students' behavior and attitudes. Arch Sexual Behav 2001;30(2):101-18.

19. McKenna KY, Bargh JA. Plan 9 from cyberspace: The implications of the Internet for personality and social psychology. Personal Soc Psychol Rev 2000;4(1):57-75.

20. Staley C, Prause N. Erotica viewing effects on intimate relationships and self/partner evaluations. Arch Sexual Behav 2013;42(4):615-24.

21. Sahay S, Nirmalkar A, Sane S, Verma A, Reddy S, Mehendale S. Correlates of sex initiation among school going adolescents in Pune, India. Indian J Pediatr 2013;80(10):814-20.

22. Singh K, Srivastava SK. Child abuse psychological effect and measurement. Indian J Health Wellbeing 2013;4(9):1742-8.

23. Short MB, Black L, Smith AH, Wetterneck CT, Wells DE. A review of Internet pornography use research: Methodology and content from the past 10 years. Cyberpsychol Behav Soc Network 2012;15(1):13-23. 
Acknowledgements - Nil

Source of Funding - Nil

Conflict of Interest - Nil

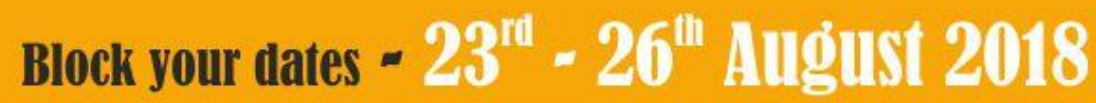

\section{Indian Association of Biological Psychiatry (IABP)}

\section{Presents}

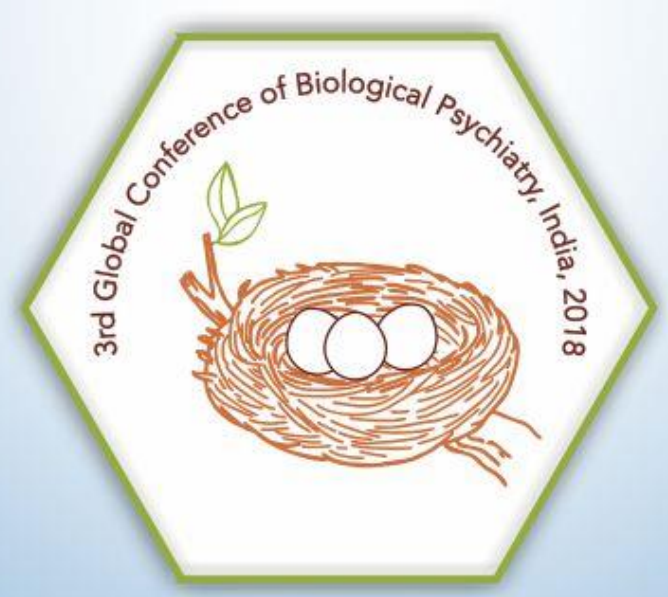

Theme:

Translational Neurobiology and Clinical Psychiatry

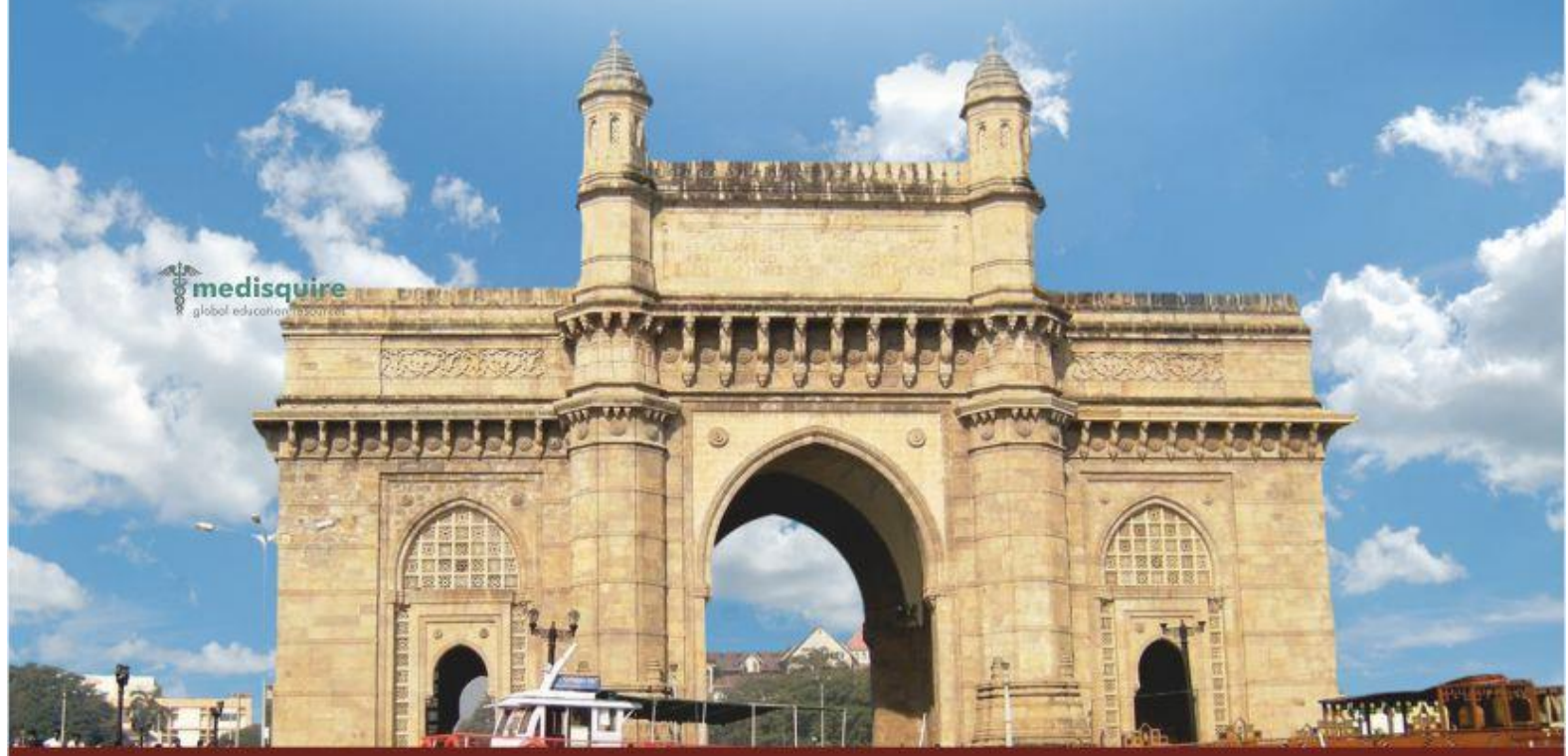

To register : Call - +022 61053811 / 12 or Email - info@medisquire.com 